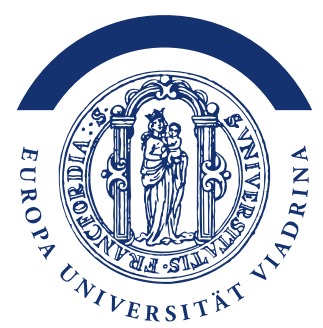

\title{
Money illusion in free-to-play games
}

Behailu Shiferaw Benti

Dominik Haß

Georg Stadtmann

European University Viadrina Frankfurt (Oder)

Department of Business Administration and Economics

Discussion Paper No. 422

March 2021

ISSN 18600921 


\title{
Money illusion in free-to-play games
}

\author{
Behailu Shiferaw Benti ${ }^{a}$, Dominik Haß ${ }^{b}$ and Georg Stadtmann ${ }^{c}$
}

March 2021

\begin{abstract}
Regularly, free-to-play games use their own virtual currency for in-game store purchases. We analyze the money illusion phenomenon by examining free-to-play games and their virtual currency exchange rate policies. We find that above pari exchange rates and advertising bonus packs instead of price discounts lead to money illusion on the side of the customer. Based on our findings, we derive managerial and policy implications.
\end{abstract}

Keywords: Money illusion, free-to-play games, virtual currency exchange rate, price incentives, bonus pack versus price discount

JEL codes: D18, L88, M37, Z28

${ }^{a}$ Behailu Shiferaw Benti, European University Viadrina, E-Mail: Benti@europa-uni.de

${ }^{b}$ Dominik Haß, European University Viadrina.

${ }^{c}$ GEORG STADTMANN, European University Viadrina, Economics and Economic Theory, Post Box 1786, 15207 Frankfurt (Oder), Germany, Tel.: +49 03355534 2700, E-Mail: stadtmann@europa-uni.de and University of Southern Denmark, Odense. 


\section{Introduction}

In the traditional video game industry, premium games were sold to customers at a specific price. This business model is referred to as "one price, one service" (Vaudour and Heinze 2020). In the last few years, the predominant business model has been freemium, where games are provided at a price of zero. This business model has a low entry barrier for the customer. In 2019, freemium games accounted for $80 \%$ of total gaming industry revenue (SuperData 2020). Therefore, the past decade has seen a radical shift in the business model of the gaming industry, where the biggest-grossing video games, such as Fortnite and League of Legends are provided free of charge. These constantly updated games are more social, more competitive, and mostly addictive. Microtransactions in the in-game stores are the major sources of revenue (The Economist 2020).

In the in-game stores, virtual currencies - which are sold for real money - are used as a medium of exchange. Two price settings are thus crucial: The first is the exchange rate policy and hence the amount of virtual currency that can be acquired by one unit of real currency (such as EUR or USD). ${ }^{1}$ The second is the price structure for different sizes of package. Game developers carry out price differentiation, where packages with larger quantities have higher exchange rates. This leads to a situation of multiple exchange rates. Such price incentives are intended to persuade consumers to spend more. Price discounts or bonus packs are two forms of sales promotions. These forms might be economically equivalent, but are psychologically different. They are therefore policy instruments that can be used to boost profitability.

The money illusion is defined as a situation when economic agents fail to perceive the real value of a unit of money. This happens when people focus on the nominal value (face value) of money rather than the real value (Fisher 2009). The phenomenon of money illusion can be observed when, for example, tourists visit a foreign country where they have to deal in a currency they are unfamiliar with. In this paper, we examine the level of exchange rates and the choices of advertisement strategies in connection with the phenomenon of money illusion.

The structure of this paper is as follows. Section 2 provides a brief review of the empirical evidence on the phenomenon of money illusion concerning exchange rates as well as sales promotion strategies. Section 3 presents the methods used and the results of the empirical analysis. Section 4 concludes.

\footnotetext{
${ }^{1}$ See Stadtmann et al. (2020) for an analysis of the exchange rate policy within the Fortnite game. The main finding is that price deviations from the Law of One Price are lower than for the well known BigMac-Index.
} 


\section{Money illusion}

\subsection{Exchange rate}

In the following, we discuss the effect of exchange rates on the cognitive perception of prices and the accompanying purchase intention of consumers. For this purpose, from the total of six experiments conducted by Raghubir et al. (2012), studies 1, 3, 4 and 5 are summarized. Based on these observations, we construct three hypotheses that are afterwards examined in the context of video game developers' pricing policies.

Study 1 shows that the way the nominal value of the foreign currency is presented leads to an underestimation or overestimation of the actual consumption expenses. Data were gathered through a laboratory experiment. Participants were asked to imagine that they worked and lived in three foreign countries. Three sets of exchange rates were then announced (1 Irish Punt/1 EUR; 0.5 GBP/ 1 EUR and 2 DEM/1 EUR). Each participant was asked to "buy" a shopping basket of 14 items (costing a true value of 46.96 EUR) and then to identify the actual value of the basket in their home country's currency. These values were then converted to Euros.

The result of the study confirmed that when the Euro was presented as a multiple of the local currency (the case where $1 \mathrm{EUR}=0.5 \mathrm{GBP}$ ), the value of the purchase was overestimated. When the Euro was presented as a fraction of the local currency (the case where 1 EUR $=2$ DEM), the value was underestimated (Raghubir et al. 2012, p. 11).

The major implication is that when the exchange rate is above par, for example, $1 \mathrm{EUR}$ $=2$ DEM, customers underestimate spending. Underestimation of the price leads to an overestimation of the value of the product and then an increase in the intention to buy.

Studies 3 to 5 in Raghubir et al. (2012) investigate consumers' price perception and purchase intention when they are faced with exchange rates that are difficult to compute (where, for example, a simple division by 2 would not reveal the actual value of the currency). Such conversion difficulties and consumers' rounding decisions affect the perception of prices and the purchase intentions. As opposed to the case where the exchange rates are easily convertible, customers faced with conversion difficulties underestimate the prices and develop a higher purchase intention (Raghubir et al. 2012, p. 12-15).

These results reflect the significant impact of exchange rate settings on the money illusion. In narrowing the focus to the gaming industry, the money illusion, in connection with the virtual currency exchange rates, can be investigated. Accordingly, the following two hypotheses are formulated: 
Hypothesis 1: In setting exchange rates, the game developers implement above par exchange rates between the virtual and real currencies.

Hypothesis 2: Video game developers opt for a conversion rate which makes it difficult for the player to convert virtual prices back into real currency.

\subsection{Discounts and bonus packs}

Promotional campaigns involve framing strategies that could play an important role in creating a money illusion. Lehdonvirta and Castronova (2014) states that non-rational decision-making by consumers is influenced by the presence of an inferior alternative for example in terms of price - on the list. Such an alternative is called a decoy option, which is defined as: an alternative that is asymmetrically dominated by one other item in the set. The decoy option increases the probability of choosing the other dominating item (Huber et al. 1982). Using a range of experiments, Ariely (2010) looks into the impact of decoy options. Its presence had forced consumers to change their preferences, since it makes other packages relatively attractive. This strategy of sellers thus motivates consumers to go for higher packages, which in turn boosts revenue.

Other forms of sales promotion strategies that are often used to influence the buying behavior of customers are discounts on price and bonus packs. In marketing, discounts are typically based on a percentage reduction of prices. When prices are lowered by applying a discount, the cognitively perceived value increases, and the customers' buying intentions would be higher (Alford and Biswas 2002, p. 775). Bonus packs, on the other hand, aim at the quantity of the product by giving the customer the possibility of acquiring more of the product at the same price (Mishra and Mishra 2011).

These two forms of sales promotion are economically equivalent. However, the customers' preference for the one over the other depends on the settings and customers' tendencies to neglect the base value associated with percentages (Chen et al. 2012, p. 64).

Sales in in-game stores are important determinants of the revenue streams of game developers. Thus, strong sales promotion strategies that influence customers' spending are put in place to increase the amount of virtual currencies sold (Schöber and Stadtmann 2020). For instance, Fortnite has a basic package where 1,000 V-Bucks (Fortnite's virtual currency) are sold for 7.99 EUR. In package 4, 13,500 V-Bucks are offered for 79.99 EUR. In case a customer buys ten basic packages, they acquire 10,000 V-Bucks. Thus, the bonus offered in package 4 amounts to $35 \%$ (i.e., $\frac{13,500 / 79.99}{1,000 / 7.99}-1 \approx 0.35$ ). In package 4 , the price per $1,000 \mathrm{~V}$-Bucks is $5.93 \mathrm{EUR}$ (i.e. $\frac{1,000 \cdot 79.99}{13,500} \approx 5.93$ ). Compared to the basic package, the price discount in package 4 is $26 \%$ (i.e. $1-\frac{1,000 / 7.99}{13,500 / 79.99} \approx 0.26$ ). Fortnite opts to promote package 4 with a bonus instead of the price discount. However, the 
equivalence is not directly obvious to the consumer: When faced with the decision between a $26 \%$ price discount or a $35 \%$ bonus, consumers most frequently opt for the bonus.

In accordance with these examples, the following hypothesis, which will be investigated in the next section, is presented.

Hypothesis 3: Money illusion is created through price discounts and bonus packs offered.

\section{Empirical evidence on the money illusion in free-to-play games}

\subsection{Data set and method}

Table 1 summarizes the ten top-selling free-to-play games of 2019 based on the report from SuperData (2020). It presents the ranking of each game, the names of the virtual currencies used, the game publishers, the platforms of the game, the revenue in billion USD, and the average virtual currency exchange rates.

Table 1: Top ten free-to-play games of 2019

\begin{tabular}{||c|l|l|l|l|c|c||}
\hline \hline Rank & \multicolumn{1}{|c|}{ Game } & $\begin{array}{l}\text { Virtual } \\
\text { Currency }\end{array}$ & Publisher & Platform & $\begin{array}{c}\text { Revenue } \\
\text { in Bill. } \\
\text { USD }\end{array}$ & $\begin{array}{r}\text { Average } \\
\text { Exchange } \\
\text { Rate }\end{array}$ \\
\hline 1 & Fortnite & V-Bucks & $\begin{array}{l}\text { Epic } \\
\text { Games }\end{array}$ & $\begin{array}{l}\text { Mobile, PC } \\
\text { \& Console }\end{array}$ & 1.8 & 147.57 \\
\hline 2 & $\begin{array}{l}\text { Dungeon } \\
\text { Fighter } \\
\text { Online }\end{array}$
\end{tabular}

Source: Apart from the data reported by SuperData (2020), the virtual currencies used, their corresponding price to construct the exchange rate and the game platforms were obtained from the game developers' websites and in-game stores. * Original prices in USD are converted to Euro.

** The game Honor of Kings is available only for the Chinese market. For our data analysis, the game Arena of Valor, which is an international adaptation of Honor of Kings, is considered.

For the empirical analysis, we first consider the virtual currency prices reflected in the in-game stores. In each store, there are multiple packages of virtual currencies 
offered. We define the minimum amount of virtual currency as the basic package. For example, Fortnite offers four different packages (1,000, 2,800, 5,000 and 13,500 V-Bucks). The average exchange rate (the amount of virtual currency per 1 EUR) reported in Table 1 is computed by considering all availed packages per game. In addition, we consider each package with its corresponding price and quantity information individually to construct a total of 55 virtual currency exchange rate observations.

In the next step, we analyze the price discounts and bonus packs offered. First, the price discount for each package is calculated. Equation (1) gives the procedure.

$$
\text { Price discount }_{i} \%=\left(1-\frac{V C_{1} / P_{1}}{V C_{i} / P_{i}}\right) \cdot 100
$$

Package 1 is the basic package offered with the basic price $P_{1}$ and virtual currency amount of $V C_{1}$. Package $i$ is a larger package with a price of $P_{i}$ and corresponding virtual currency amount $V C_{i}$. The resulting percentage is thus considered to be the price discount percentage offered in package $i$.

The bonus pack percentage is calculated by first computing the amount of virtual currency that can be bought with the price given in the basic package. Then this amount is subtracted from the actual virtual currency amount offered in the package. The resulting difference, as a percentage of the virtual currency that can be bought with the package price, is thus considered to be the bonus pack percentage offered in package $i$. Equation (2) below presents the procedure followed.

$$
\text { Bonus pack } \%=\left(\frac{V C_{i} / P_{i}}{V C_{1} / P_{1}}-1\right) \cdot 100
$$

Finally, we have cross-checked whether these observations are actually advertised with the label price discounts or bonus packs in the in-game store.

\subsection{Results}

Hypothesis 1: In setting exchange rates, the game developers implement above par exchange rates between the virtual and real currencies.

An above par exchange rate is confirmed when considering the average virtual currency exchange rates from each game reported in Table 1 (last column). For the exchange rate to be at par, the average virtual currency exchange rates should be equal to 1 . However, as can be seen, all the exchange rates are greater than 1, which provides supporting evidence for being above par. 
We consider the 55 virtual currency exchange rate observations to analyze whether the above par exchange rate is prevailing across all the virtual currency packages offered. For all the packages available per game, Table 2 summarizes the amount of virtual currency, the corresponding price, and the exchange rate. The exchange rates are obtained by simply dividing the virtual currency amount by its corresponding price which then gives the quantity of virtual currency that can be purchased by 1 EUR.

Table 2: Virtual currency prices and exchange rates

\begin{tabular}{|c|c|c|c|c|c|c|c|c|}
\hline $\begin{array}{l}\text { Virtual } \\
\text { currency }\end{array}$ & Price & $\begin{array}{l}\text { Exchange } \\
\text { rate }\end{array}$ & $\begin{array}{l}\text { Virtual } \\
\text { currency }\end{array}$ & Price & $\begin{array}{l}\text { Exchange } \\
\text { rate }\end{array}$ & $\begin{array}{l}\text { Virtual } \\
\text { currency }\end{array}$ & Price & $\begin{array}{l}\text { Exchange } \\
\text { rate }\end{array}$ \\
\hline \multicolumn{3}{|c|}{ Fortnite } & \multicolumn{3}{|c|}{ Candy Crush Saga } & \multicolumn{3}{|c|}{ Fate/Grand Order ${ }^{*}$} \\
\hline 1000 & 7.99 & 125.16 & 10 & 2.29 & 4.37 & 1 & 0.81 & 1.23 \\
\hline 2800 & 19.99 & 140.07 & 50 & 8.99 & 5.56 & 5 & 3.27 & 1.53 \\
\hline 5000 & 31.99 & 156.30 & 100 & 16.99 & 5.89 & 18 & 9.83 & 1.83 \\
\hline \multirow{3}{*}{13500} & 79.99 & 168.77 & 250 & 32.99 & 7.58 & 41 & 19.67 & 2.08 \\
\hline & & & 500 & 59.99 & 8.33 & 76 & 32.79 & 2.32 \\
\hline & & & 1000 & 109.99 & 9.09 & 167 & 65.59 & 2.55 \\
\hline Dungeon & \multicolumn{2}{|c|}{ Fighter Online * } & \multicolumn{3}{|c|}{ Pokémon GO } & \multicolumn{3}{|c|}{ Game for Peace (PUBG) } \\
\hline 100 & 0.82 & 121.95 & 100 & 0.99 & 101.01 & 60 & 1.09 & 55.05 \\
\hline 500 & 4.1 & 121.95 & $550^{* *}$ & 5.49 & 100.18 & 325 & 4.99 & 65.13 \\
\hline 1000 & 8.2 & 121.95 & 1200 & 10.99 & 109.19 & $660^{* *}$ & 10.99 & 60.05 \\
\hline 2000 & 16.4 & 121.95 & 2500 & 21.99 & 113.69 & 1800 & 27.99 & 64.31 \\
\hline 3000 & 24.6 & 121.95 & 5200 & 43.99 & 118.21 & 3850 & 54.99 & 70.01 \\
\hline 4000 & 32.8 & 121.95 & 14500 & 109.99 & 131.83 & 8100 & 109.99 & 73.64 \\
\hline \multicolumn{3}{|c|}{ Arena of Valor } & \multicolumn{3}{|c|}{ Crossfire ${ }^{*}$} & \multicolumn{3}{|c|}{ Last Shelter } \\
\hline 100 & 1.09 & 91.74 & 15000 & 7.37 & 2034.78 & 300 & 5.49 & 54.64 \\
\hline $500^{* *}$ & 5.49 & 91.07 & 30000 & 14.34 & 2091.79 & 1200 & 10.99 & 109.19 \\
\hline 1200 & 10.99 & 109.19 & 75000 & 35.25 & 2127.55 & $1600^{* *}$ & 20.99 & 76.23 \\
\hline 2500 & 21.99 & 113.69 & 150000 & 65.59 & 2286.87 & 8000 & 54.99 & 145.48 \\
\hline 6500 & 54.99 & 118.20 & & & & 20000 & 109.99 & 181.83 \\
\hline 14000 & 109.99 & 127.28 & & & & & & \\
\hline \multicolumn{3}{|c|}{ League of Legends } & & & & & & \\
\hline 310 & 2.5 & 124.00 & & & & & & \\
\hline 650 & 5 & 130.00 & & & & & & \\
\hline 1380 & 10 & 138.00 & & & & & & \\
\hline 2800 & 20 & 140.00 & & & & & & \\
\hline 5000 & 35 & 142.86 & & & & & & \\
\hline 7200 & 50 & 144.00 & & & & & & \\
\hline
\end{tabular}

* Original prices in USD are converted to EUR. Exchange rate 1 USD $=0.82$ EUR in February, 2021.

** Decoy options.

Source: Own representation.

All the exchange rates are tremendously larger than 1 . Therefore, we conclude that game developers set exchange rates above par, which then leads to the money illusion on the part of the private customers.

Hypothesis 2: Video game developers opt for a conversion rate which makes it difficult for the player to convert virtual prices back into real currency.

From Table 2 it is also evident that, with an exception in the case of League of Legends, these exchange rates are difficult to compute when customers want to know the price in real currency (EUR or USD). Both the computed exchange rates and the prices from the list are mostly indicated with two decimal places. Therefore, it becomes clear that an easy rule of thumb (such as "divide by 2") is not applicable. We, thus, conclude that 
the computational difficulties attached to the exchange rates could again lead to the money illusion on the part of the private customers.

Figure 1: Average price discounts and bonus packs per game

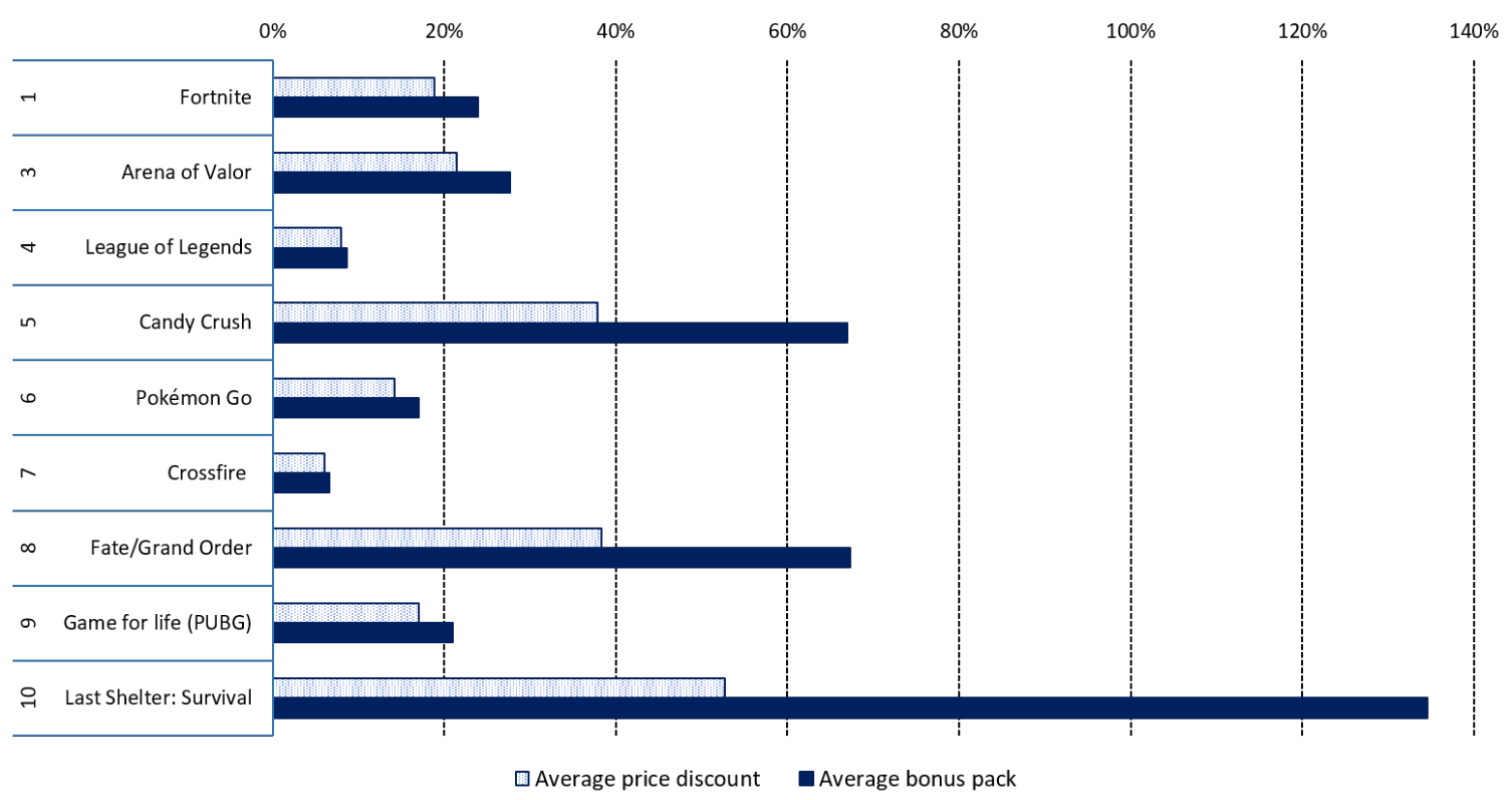

Source: Own representation.

Hypothesis 3: Money illusion is created through price discounts and bonus packs offered.

Examining Table 2 in more detail reveals that some game developers follow a strategy of adding decoy options. We operationalize the given definition of decoy option for our case as follows: A decoy option is an alternative where the exchange rate (virtual currency/EUR) decreases as the package size increases. For example, Arena of Valor offers 100 Vouchers for 1.09 EUR - so that the exchange rate is 91.74 Vouchers/EUR. Package 2 offers 500 Vouchers at 5.49 EUR so that the exchange rate is now only 500 Vouchers/5.49 EUR $=91.07$ Vouchers/EUR. Buying 5 packages in the basic package would only cost $5 \cdot 1.09 \mathrm{EUR}=5.45 \mathrm{EUR}$ instead of $5.49 \mathrm{EUR}^{2}$. An even more extreme example is Last Shelter: Survival where in package 2, 1200 Diamonds are sold at 10.99 EUR i.e. an exchange rate of 109.19 Diamonds/EUR. In package 3, however, 1600 Diamonds are sold at 20.99 EUR resulting in an exchange rate of only 76.23 Diamonds/EUR. ${ }^{3}$

\footnotetext{
${ }^{2}$ Similar decoy options are observed in Pokémon GO (package of 550 Poké Coins) and Game for Peace (PUBG) (package of $660 U C)$.

${ }^{3}$ Buying two packages of 1200 Diamonds costs 21.98 EUR $(2 \cdot 10.99$ EUR). However, it is definitely clear that no customer would pay 20.99 EUR for only 1600 Diamonds while having the possibility of getting 2400 Diamonds by paying additionally a marginal amount of 0.99 EUR $(21.98-20.99)$.
} 
Figure 1 depicts the average price discount and bonus pack percentage as computed using Equations (1) and (2). These two forms of sales promotion are regarded as economically equivalent but psychologically different. As seen from the figure, the average bonus pack percentages are higher than the average price discount percentages. Although the extent differs, this applies to the nine top-selling free-to-play games of 2019. It is important to mention here that Dungeon Fighter Online doesn't offer any form of price discount.

Figure 2: Forms of bonus packs promoted

(a) League of Legends

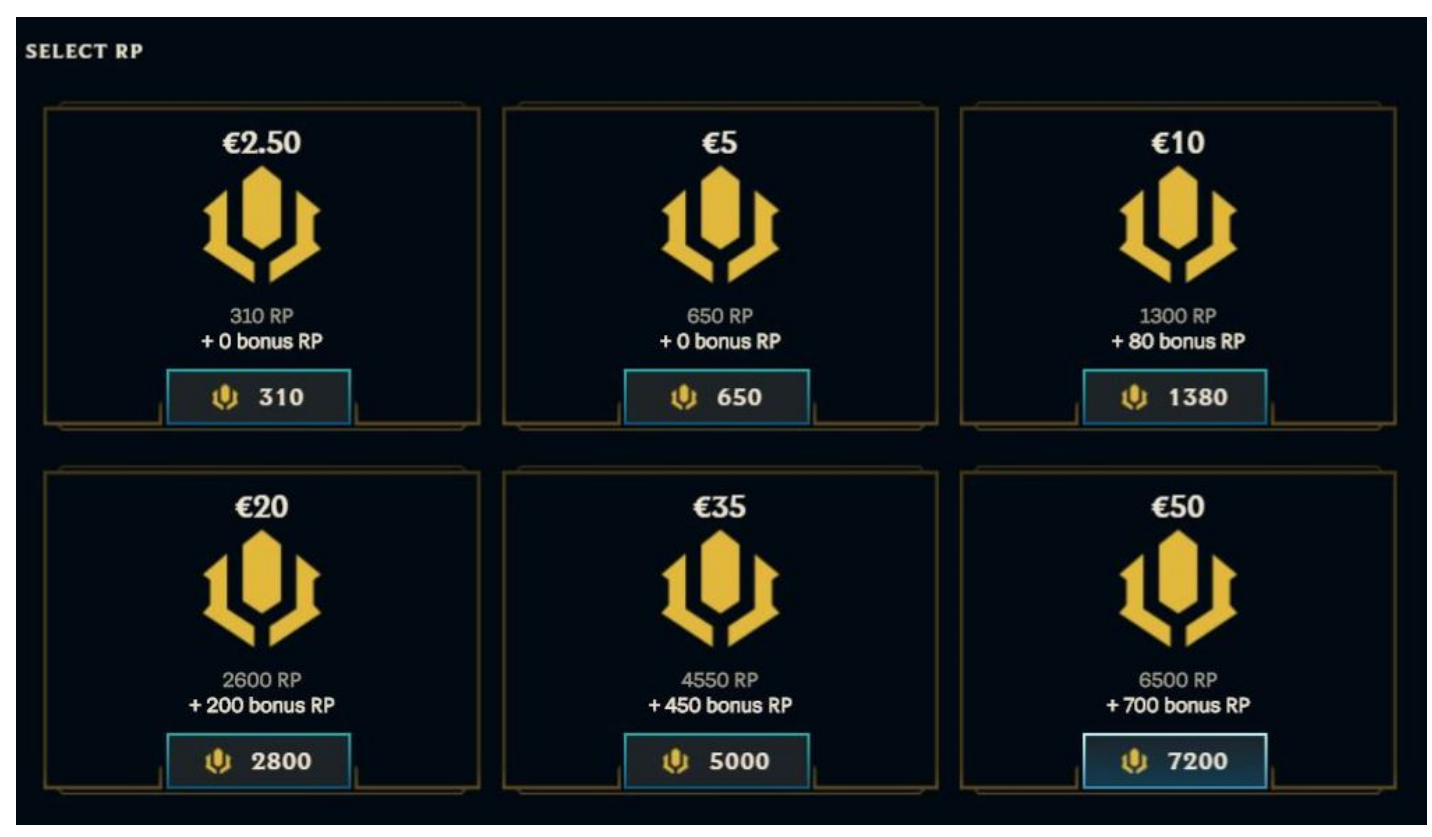

(b) Fortnite

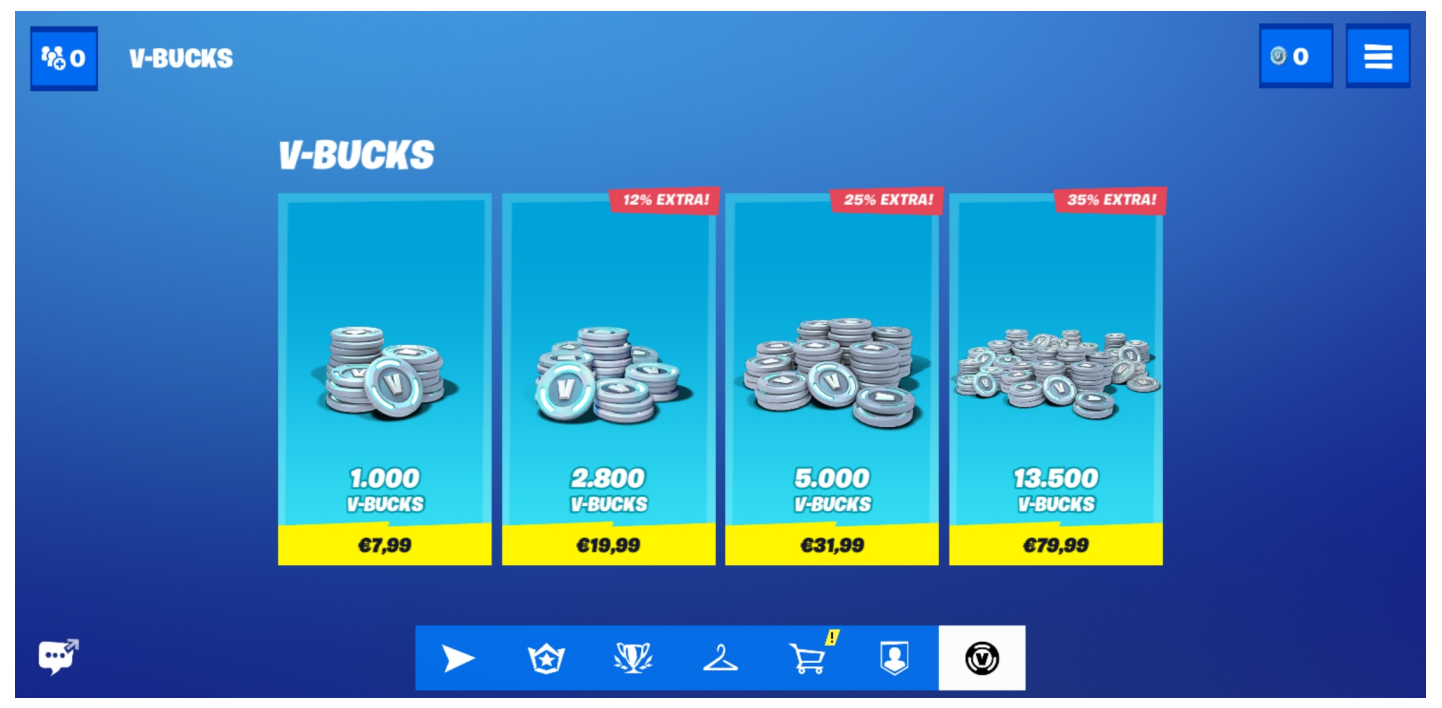

Source: Screen captures from the in-game stores.

Difference: While League of Legends advertises in absolute value, Fortnite advertises in percentage terms. Both games advertise bonus instead of price discount. 
To further concretize, we have extended our analysis by first identifying which packages are actually promoted by game developers. We have found 23 packages from six free-to-play games ${ }^{4}$ are promoted in the respective in-game stores.

A common observation in all six games is that game developers promote the bonus pack instead of the price discount. Some in-game stores promote the bonus quantity of virtual currency awarded per package. Some others promote the percentage of the awarded virtual currency relative to the basic package. The first form of promotion is for example followed by League of Legends (Figure 2a) while Fortnite (Figure 2b) opts for the second form.

\section{Conclusions}

We examined the concept of money illusion in the gaming industry. The paper identified conditions leading to a possible money illusion. For the empirical analysis, three hypotheses that revolve around the observed exchange rates of the in-game currencies and the advertising strategies of the game developers have been conceptualized. We have argued that these factors are supported with empirical evidence and are vital for creating the money illusion on the part of the customers, so as to boost revenue and profits.

Summary: Hypotheses 1 and 2 were tested by first observing the average virtual currency exchange rates per game. Subsequently, individual packages offered in the in-game store were considered so as to look into the virtual exchange rates applied. It was confirmed that the face values of the virtual currency exchange rates are above par. In addition, we have noticed that the conversions of the exchange rates are difficult to compute. These two findings are thus helpful for highlighting that the money illusion is created by the game developers in the gaming industry. Finally, in line with Hypothesis 3 , we have first confirmed that $40 \%$ of the game developers have deployed decoy options that would influence customers' decision making. In addition, the difference between price discounts and bonus packs in the virtual currency packages offered has been analyzed. It was confirmed that the game developers opt to advertise their packages with bonus packs instead of price discounts. These two alternatives are deemed economically equivalent but not psychologically. The bonus pack is always higher than the price discount percentage. The choice of the game developers to advertise the bonus pack is thus regarded as another factor in creating the money illusion in the gaming industry. In general, as long as they are not regulated, both the exchange rate setting and advertising strategies of the game developers are creating the money illusion on the part of the

\footnotetext{
${ }^{4}$ Apart from Dungeon Fighter Online, although packages are offered with price incentives, the games Arena of Valor, Candy Crush Saga and Pokémon Go do not advertise any price discount or bonus pack.
} 
consumers.

Policy implications: Cerulli-Harms et al. (2020) recently published a report for the European Parliament Committee on the Internal Market and Consumer Protection (IMCO). The report focuses on the behavioral effects of loot boxes ${ }^{5}$ and the corresponding regulatory framework in the EU. A particular further research recommendation from this study focuses on looking at a broader perspective of the gaming industry in addressing consumer protection (Cerulli-Harms et al. 2020, p. 42).

In February 2021, a class action lawsuit was filed against Epic Games - the publisher of the Fortnite game - in California. The action states that Epic Games misleads and manipulates in-game spending of minors by making conversion rates of V-Bucks difficult. With these difficulties, players - especially minors - are not able to determine the real cost of their in-game purchase, which in turn is creating a high degree of money illusion (Class Action 2021).

We believe that this paper provides a broader perspective on the money illusion in the gaming industry. Thus, our major policy implication is that the money illusion highly influences the purchase intentions of players. Firstly, the less transparent exchange rate settings that are difficult to compute lead to overspending. Second, the strict focus on advertising bonus packs creates misconceptions. In this regard, a further investigation is recommended.

\footnotetext{
5 "Loot boxes are features in video games which are usually accessed through gameplay, or which may optionally be paid for with real-world money. They are 'mystery boxes' which contain randomized items, so players do not know what they will get before opening." (Cerulli-Harms et al. 2020, p. 14).
} 


\section{References}

Alford, B.L., and A. Biswas (2002) "The effects of discount level, price consciousness and sale proneness on consumers' price perception and behavioral intention" Journal of Business Research 55(9), 775-783.

Ariely, D. (2010) Predictably Irrational: The Hidden Forces That Shape Our Decisions, Harper: New York.

Cerulli-Harms, A, M. Münsch, C. Thorun, F. Michaelsen, and P. Hausemer (2020) "Loot boxes in online games and their effect on consumers, in particular young consumers" Publication for the Committee on the Internal Market and Consumer Protection (IMCO), Policy Department for Economic, Scientific and Quality of Life Policies, European Parliament, Luxembourg, 202. https://www . europarl . europa.eu/Reg Data/etudes/STUD/2020/652727/IPOL_STU(2020)652727_EN . pdf

Chen, H., H. Marmorstein, M. Tsiros, and A.R. Rao (2012) "When more is less: The impact of base value neglect on consumer preferences for bonus packs over price discounts" Journal of Marketing 76(4), 64-77.

Class Action (2021) "The Epic Games Class Action Lawsuit is Williams, et al. v. Epic Games, Inc., Case No. 3:21-cv-00976" in the United States District Court for the Northern District of California. https://www.classaction.org/media/kw-etal-v-epic-games-inc.pdf

Fisher, I. (2009) The Money Illusion, Snowball Publishing.

Huber, J., J.W. Payne, and C. Puto (1982) "Adding asymmetrically dominated alternatives: Violations of regularity and the similarity hypothesis" Journal of Consumer Research 9(1), 90-98.

Lehdonvirta, V., and E. Castronova (2014) Virtual Economies: Design and Analysis, MIT Press.

Mishra, A., and H. Mishra (2011) "The influence of price discount versus bonus pack on the preference for virtue and vice foods" Journal of Marketing Research 48(1), 196-206.

Raghubir, P., V.G. Morwitz, and S. Santana (2012) "Europoly money: How do tourists convert foreign currencies to make spending decisions?" Journal of Retailing 88(1), $7-19$

Schöber, T., and G. Stadtmann (2020) "Fortnite: The business model pattern behind the scene" Die Unternehmung 74(4), 426-444.

Stadtmann G., C. Pierdzioch, and T. Schöber (2020) "Law of one price: BigMac versus Fortnite - A Note" Economics Bulletin 40 (4), 3338-3348. 
SuperData (2020) "2019 Year in Review: Digital Games and Interactive Media" SuperData-A Nielsen Company.

The Economist (2020) "Legends in lockdown: The pandemic has accelerated the growth of e-sports" June 27, 2020, https://www . economist.com/international/2020/0 6/27/the-pandemic-has-accelerated-the-growth-of-e-sports.

Vaudour, F., and A. Heinze (2020) "Software as a service: Lessons from the video game industry" Global Business and Organizational Excellence 39(2), 31-40. 